\title{
Spatial and temporal variation in Anguillicola crassus counts: results of a 4 year survey of eels in Mediterranean lagoons
}

\author{
F. Lefebvre, P. Contournet, F. Priour, O. Soulas, A. J. Crivelli* \\ Station Biologique de la Tour du Valat, Le Sambuc, 13200 Arles, France
}

\begin{abstract}
We present the results of a survey of anguillicolosis in the Rhône River delta. From January 1997 to December 2000, a total of 13319 eels (Anguilla anguilla from elver to silver phase) were examined, in which we found 22227 swimbladder nematodes (Anguillicola crassus adults and preadults). A generalised linear model (GLM) framework was used to explore the relative contribution of various factors to the occurrence, intensity and abundance of the parasite. We reveal a major influence of the month of sampling, and we document the existence of a seasonal pattern with regular peaks in early summer and late winter. In contrast, the year of sampling is of secondary importance, and no particular trend in the development of the infection can be detected. More than a decade after the first record of A. crassus in the Rhône River delta, anguillicolosis has thus attained a constant infection rate of nearly $50 \%$, with a mean number of 3 or 4 macroscopic lumen worms per infected eel. The eel length strongly influences the intensity and the abundance of the nematode, but has little if any effect on the probability of being infected. There exists a linear relationship between eel size and the number of parasites, but not between eel size and prevalence. We observe a decrease in the proportion of infected individuals among elver eels. We discuss this result in relation to the possible mortality of heavily infected individuals and/or a change in the eels' alimentary diet.
\end{abstract}

KEY WORDS: Epidemiology · Anguillicolosis · Anguilla anguilla $\cdot$ Anguillicola crassus $\cdot$ Host-parasite system $\cdot$ Parasite distribution

\section{INTRODUCTION}

The European eel Anguilla anguilla was recently infected by the Asian swimbladder nematode Anguillicola crassus (Kuwahara et al. 1974). The parasite was brought to Europe probably as a result of importation of its native host, the Japanese eel Anguilla japonica (Peters \& Hartmann 1986). The first case of infection (i.e. anguillicolosis) was in 1982, in West Germany (Neumann 1985). In France, A. crassus was first recorded in 1985 in the Rhône River delta (Dupont \& Petter 1988). Since then, the parasite has rapidly colonised nearly all European countries, North Africa

${ }^{*}$ Corresponding author. E-mail: a.crivelli@tour-du-valat.com
(Køie 1991, Moravec 1994 and references therein), and has now arrived in the American continent (Fries et al. 1996, Barse \& Secor 1999).

As a result of the concern caused by its presence in the eel stocks, the nematode has been the focus of considerable attention. Its life cycle has been thoroughly described and completed in the laboratory (de Charleroy et al. 1990, Kennedy \& Fitch 1990, Blanc 1994). Infection occurs through the ingestion of planktonic crustaceans (copepods, ostracods) as intermediate hosts, but fishes (stickleback, goby, ruffe, pumpkinseed) and many other aquatic organisms (insect larvae, amphibians) may also act as paratenic hosts (Thomas \& Ollevier 1992, Moravec \& Škoríková 1998, Cesco et al. 2001). In the eel, the nematode larvae moult and develop within the tissue layers of the 
swimbladder wall, but pre-adult and adult worms inhabit the swimbladder lumen. Herein, lumen worms actively feed on the capillary system before they reproduce and die. At $20^{\circ} \mathrm{C}$, under laboratory conditions, the life cycle can be completed in less than 2 mo (de Charleroy et al. 1990), but may take much longer in the wild (nearly 6 mo according to Thomas \& Ollevier 1993). In fact, there are still some open questions about the temporal pattern of the infection in natural waters. Fluctuations in prevalence and intensity of the infection were generally observed across time, but for many reasons, most studies have failed to detect any seasonality (Kennedy \& Fitch 1990, Möller et al. 1991, Thomas \& Ollevier 1992, Molnár et al. 1994, Würtz et al. 1998). It is not known, however, to what extent temporal variation in other factors such as eel length may influence the observed parasite count. Generally, the number of parasites steadily increases along with the increasing host size (Thomas \& Ollevier 1992, Molnár et al. 1994, Baruš et al. 1996), but other data do not support a linear relationship (Peters \& Hartmann 1986, Würtz et al. 1998). In fact, most studies have investigated separately the importance of these factors, whereas interactions between them may generate confounding effects.

The first objective of this study was to simultaneously assess the relative contribution of various spatial and temporal factors on the parasite count. Parasitic descriptors of the infection (prevalence, intensity and abundance) were then described and discussed in relation to the major factors previously identified. Data was derived from a survey program of anguillicolosis initiated in 1997 in the Rhône River delta (Camargue, South of France). Thus, this study also documents the spread of the infection more than a decade after its first report in this area (in 1985: Dupont \& Petter 1988), which was also the first case reported in France.

\section{MATERIALS AND METHODS}

Eels were collected from brackish waters of the Rhône River delta. Two sample sites were investigated: the Vaccarès lagoon (6400 ha, mean salinity $10 \mathrm{~g} \mathrm{l}^{-1}$ ) and the Malagroy lagoon (4600 ha, mean salinity $25 \mathrm{~g}$ $\mathrm{l}^{-1}$ ). Monthly sampling was conducted over 4 consecutive years from January 1997 to December 2000 (in 1999, only 6 mo were sampled: April, May, June, September, October, November). In each site, 2 fyke nets (one with a $6 \mathrm{~mm}$ mesh in the funnels and a leading net of $40 \mathrm{~m}$, the other with $0.5 \mathrm{~mm}$ mesh and a leading net of $20 \mathrm{~m}$ ) were used to catch all size classes. The nets were set on 4 consecutive days per month and visited every $24 \mathrm{~h}$. Eels were frozen on the day of capture and examined later.
The total length (TL) of each fish was recorded to the nearest millimetre. The swimbladder of all eels was removed and macroscopically examined for the presence of Anguillicola crassus. The number of lumen worms (pre-adults and adults) was recorded. Throughout the study, the parasitic descriptors are used in accordance with the recommendations of Bush et al. (1997): each eel was classified as infected or uninfected, herein referring to the occurrence of the parasite (presence/absence data); intensity is the number of parasites in a single infected eel; abundance is the number of parasites in a single eel regardless of whether or not the eel is infected. The effects of sampling site, year, month and host length on the above 3 parasitic descriptors were explored within a generalised linear model (GLM) framework. Sampling site (Vaccarès, Malagroy), year (1997, 1998, 1999, 2000) and month were entered as categorical predictors, and TL as a continuous predictor. Intensity and abundance were fitted by a normal distribution after log-transformation $(\ln x+1)$, and an identity-link function was used. In the case of occurrence, the response variable was binomial, and a logit-link function was used. Because of missing data in the monthly sampling in 1999, some first- and second-order interactions (year $x$ month and year $\times$ month $\times$ sampling site) cannot be estimated, and for this reason only main effects were included in the models. The goodness of fit of the GLMs was checked by the ratio of the model deviance to its degree of freedom (deviance/df $<1$ ). The contribution of model terms and their significance were checked by the chi-square values $\left(\chi^{2}\right)$ of the likelihood Type 3 test (Burnham \& Anderson 1998).

Epidemiological data were then presented in relation to sampling units of time (1 mo step) or host sizeclass $(25 \mathrm{~mm}$ step). In this case, mean intensity and mean abundance are the average intensity and abundance in the sampling unit, and prevalence refers to the percentage of infected hosts within each sampling unit. Comparisons of prevalence values between host size-classes were performed by $\chi^{2}$ tests. Relationships between parasitic descriptors and host size were assessed by Spearman rank tests. Results were expressed as mean \pm SE. Graphs were all drawn on natural (not transformed) data. In the case of estimates, means were computed on a transformed scale and then de-transformed.

\section{RESULTS}

A total of 13319 eels covering all size-classes (60 to $717 \mathrm{~mm}$ in length) was examined during the $4 \mathrm{yr}$ survey. A total of 22227 Anguillicola crassus was counted in the lumens of swimbladders. The results of the 
Table 1. Anguilla anguilla. Results of generalised linear model examining effects of year, month, site and total length (TL) on prevalence, intensity and abundance of Anguillicola crassus in the eel (likelihood Type 3 tests)

\begin{tabular}{|lrrc|}
\hline Effect & $\mathrm{df}$ & $\chi^{2}$ & $\mathrm{p}$ \\
\hline Prevalence & & & \\
Year & 3 & 7.83 & $<0.05$ \\
Month & 11 & 293.74 & $<0.001$ \\
Site & 1 & 0.64 & 0.42 \\
TL & 1 & 1.96 & 0.16 \\
Intensity & & & \\
Year & 3 & 38.35 & $<0.001$ \\
Month & 11 & 175.49 & $<0.001$ \\
Site & 1 & 4.57 & $<0.05$ \\
TL & 1 & 254.17 & $<0.001$ \\
Abundance & & & \\
Year & 3 & 32.94 & $<0.001$ \\
Month & 11 & 480.29 & $<0.001$ \\
Site & 1 & 0.09 & 0.76 \\
TL & 1 & 57.62 & $<0.001$ \\
& & & \\
\hline
\end{tabular}

model are presented in Table 1. The month of sampling had a pronounced influence on the number of $A$. crassus found in the swimbladder of eels. It was the most important variable explaining occurrence and abundance. In contrast, sampling site had only a marginal effect. Data from the 2 lagoons (Vaccarès and Malagroy) may thus be pooled as a single sample. The validity of this statistical decision was supported by the large-scale connection between the 2 lagoons, which suggested the existence of a single sub-population of the European eel. For each of the above parasitic descriptors, year had a secondary but significant influence, thus precluding synthesis on an annual scale.

For the model of occurrence, the term TL was not significant, indicating that host size had little if any influence on the probability of infection. In contrast, the significant effect of TL on intensity (its major contributing factor) and abundance stressed the need to take the fish size into account in examining monthly variations in parasite counts.

\section{Temporal infection dynamics}

From January 1997 to December 2000, the prevalence in monthly samples varied between 40 and $72 \%$ (Fig. 1). Highest prevalence values were recorded in early summer (June and July) each year. Mean monthly intensity varied from $1.50 \pm 0.50$ (but $\mathrm{n}=2)$ to $7.72 \pm 1.14(\mathrm{n}=82)$ parasites per infected host with an overall mean intensity of $3.36 \pm 0.04(\mathrm{n}=6627)$ (Fig. 2A). Maximum values for mean intensity were in early summer (June and July) or late winter (January and February). Monthly mean abundance varied from $0.75 \pm 0.48(\mathrm{n}=4)$ to $5.41 \pm 0.86(\mathrm{n}=117)$ (Fig. 3A). As for mean intensity, highest values were observed either in early summer or late winter. However, since the host size was shown to have a significant effect on the parasite count (Table 1), monthly mean intensity and mean abundance values had to be corrected by eel length. The results are presented in Figs. 2B \& 3B. For each year, there was still a marked peak around June, as well as a trend for increasing values at the end of winter.

Although a significant difference between years was revealed (Table 1), there was no particular trend in the development of the infection across the $4 \mathrm{yr}$ survey. Prevalence seemed to stabilise around $50 \%$ (Fig. 1), and the mean number of parasites ranged between 3 and 4 per infected host (between 2 and 3 for host sizes of $210 \mathrm{~mm}$ length) (Fig. 2).

\section{Infection and host size}

All size-classes of eel were infected by Anguillicola crassus (Fig. 4A). The smallest infected individual was $71 \mathrm{~mm}$ long, although a low prevalence value was recorded among eels shorter than $75 \mathrm{~mm}$ (prevalence = $8 \%, \mathrm{n}=26$ in the first size-class ranging from 50 to 74 $\mathrm{mm})$. High infection rates were reached in the next 2 size classes (prevalence $=65 \%$ for 75 to $99 \mathrm{~mm}$ length, $\mathrm{n}=$

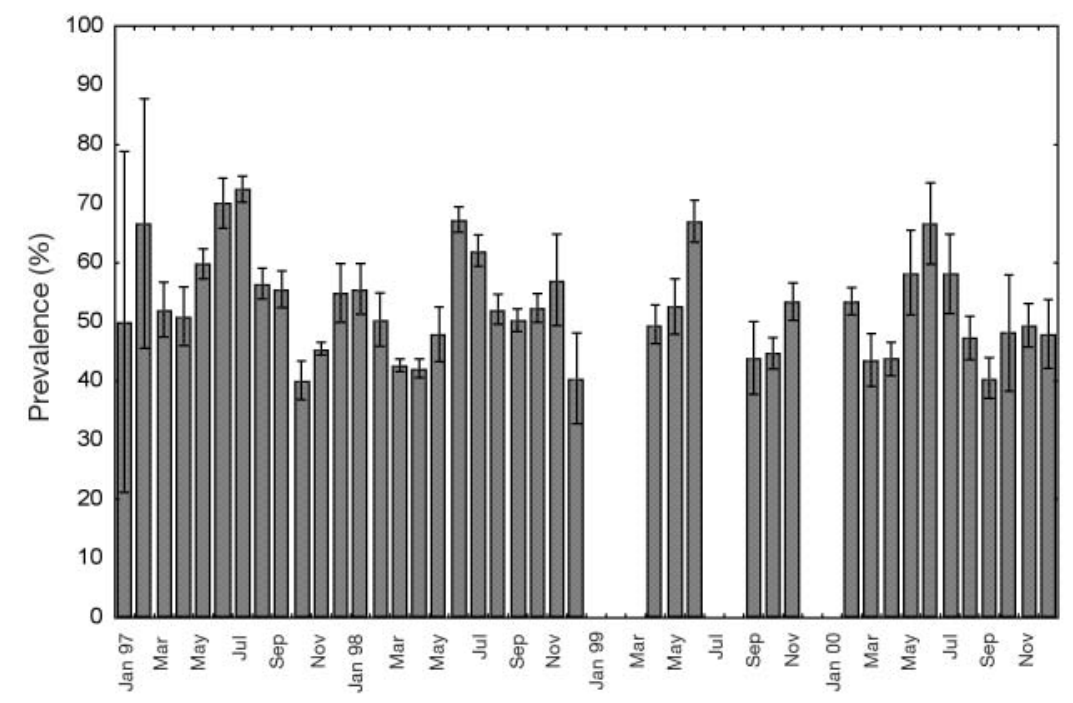

Fig. 1. Anguilla anguilla. Mean $( \pm \mathrm{SE})$ prevalence of Anguillicola crassus as a function of month of the year 
163; prevalence $=64 \%$ for 100 to $124 \mathrm{~mm}$ length, $\mathrm{n}=$ 806). There was a significant increase in prevalence between the first and the second size-classes $\left(\chi^{2}=30.10, p\right.$ $<0.001)$. In the fourth size class, prevalence values fell to $46 \%$ (125 to $149 \mathrm{~mm}, \mathrm{n}=2013$ ), and the decrease was statistically significant (third size class vs fourth size class: $\left.\chi^{2}=74.79, p<0.001\right)$. A decreasing trend was recorded up to the sixth size-class (for 175 to $199 \mathrm{~mm}$ length, prevalence $=45 \%, \mathrm{n}=2161$ ). Thereafter, prevalence increased with increasing host size, and the highest values were recorded among the largest size classes (maximum: $70 \%$ in eels longer than $600 \mathrm{~mm}, \mathrm{n}=33$ ). No significant linear correlation was found between prevalence values and overall size classes $(r=0.33, \mathrm{n}=$ $23, \mathrm{p}=0.13)$.
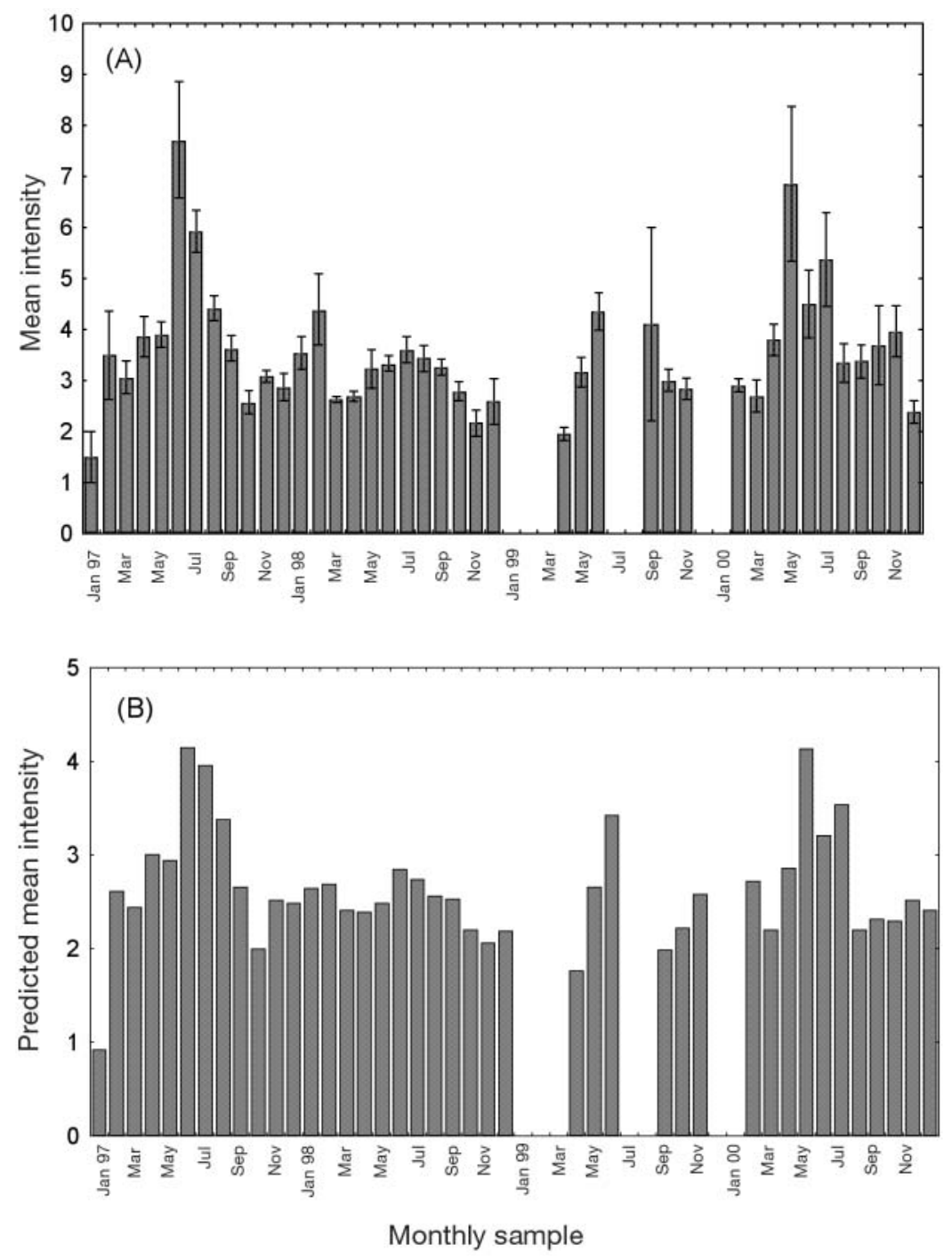

Fig. 2. Anguilla anguilla. (A) Mean $( \pm \mathrm{SE}$ ) intensity (no. of parasites per infected host) and (B) predicted mean intensity of infection by Anguillicola crassus as a function of month of the year. Predicted values based on total eel length of $210 \mathrm{~mm}$
The lowest mean intensities were observed among the smallest infected eels $(2.00 \pm 1.41$ for 50 to $74 \mathrm{~mm}$ length, $\mathrm{n}=2 ; 2.13 \pm 0.13$ for 75 to $99 \mathrm{~mm}$ length, $\mathrm{n}=$ 106). A significant positive correlation was found between intensities and TL $(\mathrm{r}=0.16, \mathrm{n}=6627, \mathrm{p}<$ 0.001 ) and between mean intensities and host sizeclasses $(r=0.92, n=23, p<0.001)$. The increase was perfectly linear for eels up to $350 \mathrm{~mm}$ long (size at silvering in males) (Fig. 4B). The highest parasite burden was 78 A. crassus in a 548 mm-long eel.

Variation in mean abundance integrated these trends in prevalence and intensity, with a bell-shaped curve for small size classes and thereafter a trend of increasing values with increasing host size (Fig. 4C). A significant positive correlation was found between mean abundance and host size-class ( $\mathrm{r}=0.89, \mathrm{n}=23, \mathrm{p}<0.001)$, but not between abundance and TL $(r=0.00$, $\mathrm{n}=13319, \mathrm{p}=0.93$ ).

\section{DISCUSSION}

The most important factors explaining variation in Anguillicola crassus count were the month of sampling for prevalence and abundance, and host length for intensity. Although there was a consistent difference in salinity between the 2 brackish lagoons (10 and $25 \mathrm{~g} \mathrm{l}^{-1}$ ), sampling site had little effect on parasitic values. It is rather surprising because salinity has been shown to have a major influence on parasite biology (Nielsen 1997, Kirk et al. 2000). In particular, parasite development and transmission appears to be lower in brackish and marine waters than in fresh waters (Kirk et al. 2000).

No particular trend in the development of the infection could be detected across the 4 years of the survey. More than a decade after the first record of Anguillicola crassus in the Rhône River delta (1985: Dupont \& Petter 1988), anguillicolosis has since reached a constant infection rate of nearly $50 \%$. Our results support the possibility of a stabilisation in the infection level, as has already been recorded in other European countries (van Willingen \& Dekker 1989, Ashworth 1994). Generally, the infection spreads rapidly in the first few years following its appearance, before stabilising around a spe- 
cific value of prevalence. The mean intensity also seems to have attained an equilibrium level. We recorded yearly means of between 3 and 4 parasites per eel (between 2 and 3 for an eel $210 \mathrm{~mm}$ in length). Although comparisons with data in the literature are obviously difficult (differences in sample size, host size, season), the mean intensities reported have rarely exceeded 5 macroscopic lumen parasites per eel. Some authors have even reported a mean threshold value of 4 adult parasites per infected eel (Ashworth 1994). Different mechanisms have been advanced to explain the nature of this phenomenon, including densitydependent effects (Ashworth \& Kennedy 1999), host adaptation (Buchmann et al. 1991, Höglund \& Pilström 1995, Kelly et al. 2000), and mortality of heavily infected individuals (Molnár et al. 1994,

Baruš \& Prokeš 1996).

Adult nematodes were found in the swimbladder of eels throughout the year (minimum prevalence of $40 \%$ ). Despite this, a temporal pattern in the parasitic descriptors was evident. Maximum values of prevalence, mean intensity and mean abundance were recorded each year in early summer and, to a lesser degree, in late winter. As previously mentioned, almost all investigations have failed to detect any seasonality (Kennedy \& Fitch 1990, Möller et al. 1991, Thomas \& Ollevier 1992, Molnár et al. 1994, Würtz et al. 1998). Nevertheless, the existence of seasonal peaks has already been noted (Benajiba et al. 1994, Hartmann 1994, Nagasawa et al. 1994). Of particular interest is the study of Benajiba et al. (1994), which also recorded biannual peaks in another brackish lagoon (Mauguio, South of France). Such periodicity tends to support the existence of a 6-month life cycle for the nematode (Thomas \& Ollevier 1993).

Infection may occur in all size classes of eels in their continental phase. We found here that the smallest infected individual was $71 \mathrm{~mm}$ long, and that a total of 108 eels smaller than $100 \mathrm{~mm}$ (57\%) already harboured lumen worms in their swimbladders. These field data are thus in total accordance with the results of laboratory experiments that have demonstrated successful inoculations of Anguillicola crassus in glass eels (de Charleroy et al. 1990, Nimeth et al. 2000). As mentioned by van Ban- ning \& Haenen (1990), this means that glass eels may become infected as soon as they arrive in continental waters (i.e. as soon as they feed on zooplankton).

We found a clear relationship between parasite intensity and host size on both a total length and a size-class basis. As already reported in earlier studies, larger eels thus harbour more parasites, smaller eels fewer parasites (Möller et al. 1991, Thomas \& Ollevier 1992, Molnár et al. 1994). This seems to be a general trend in fish-parasite systems (Dogiel et al. 1958, but see Poulin 2000 for critical review). In theory, in the absence of an effective immune response, as in the present case (Békési et al. 1997, Knopf et al. 2000), an accumulation of parasites may result from: (1) longer exposure time (i.e. older fish have had more time to accumulate para-
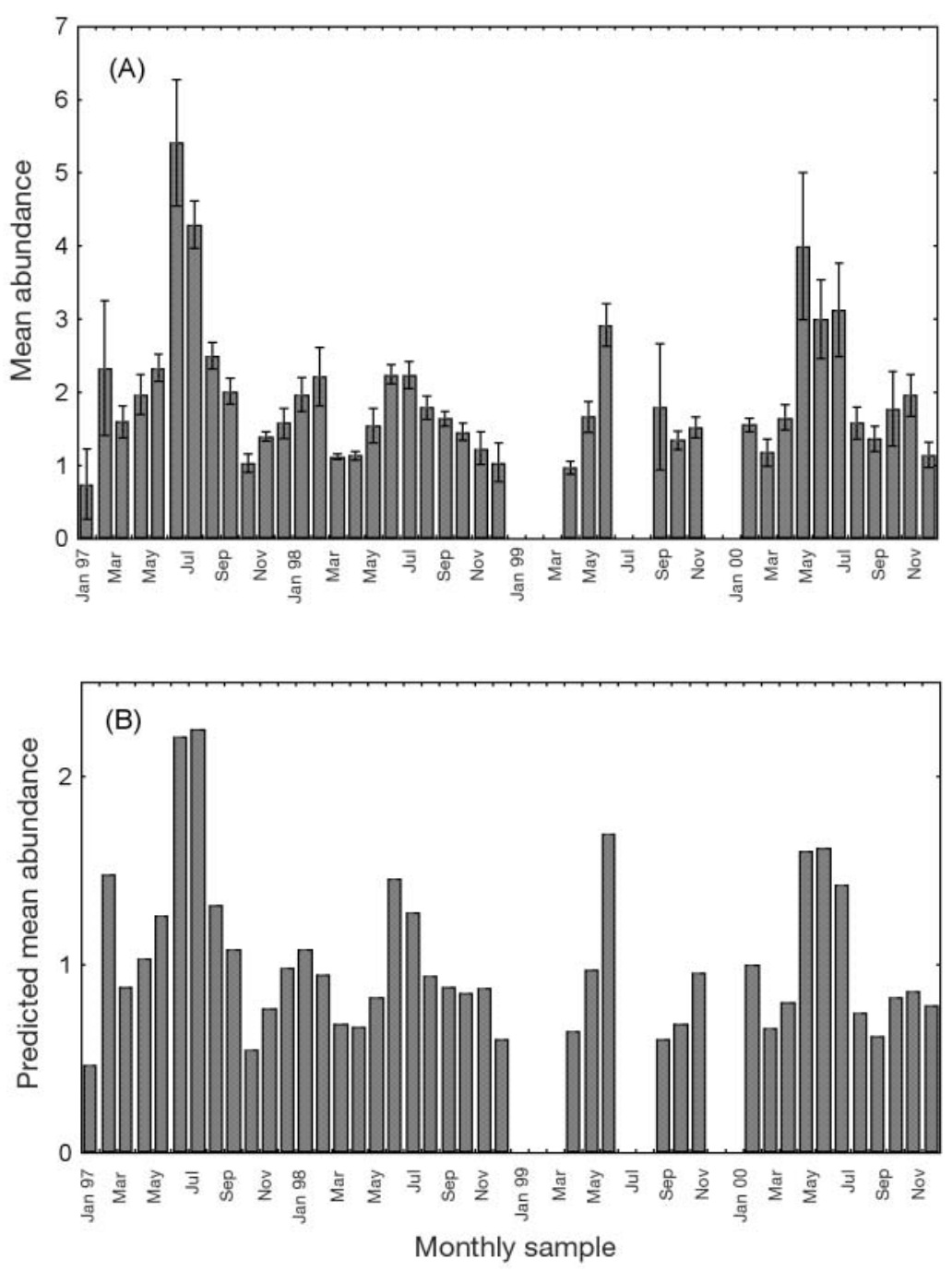

Fig. 3. Anguilla anguilla. (A) Mean $( \pm \mathrm{SE})$ abundance (no. of parasites) and (B) predicted mean abundance of Anguillicola crassus, in all eels sampled, as a function of month of the year. Predicted values based on a total eel length of $209 \mathrm{~mm}$ 

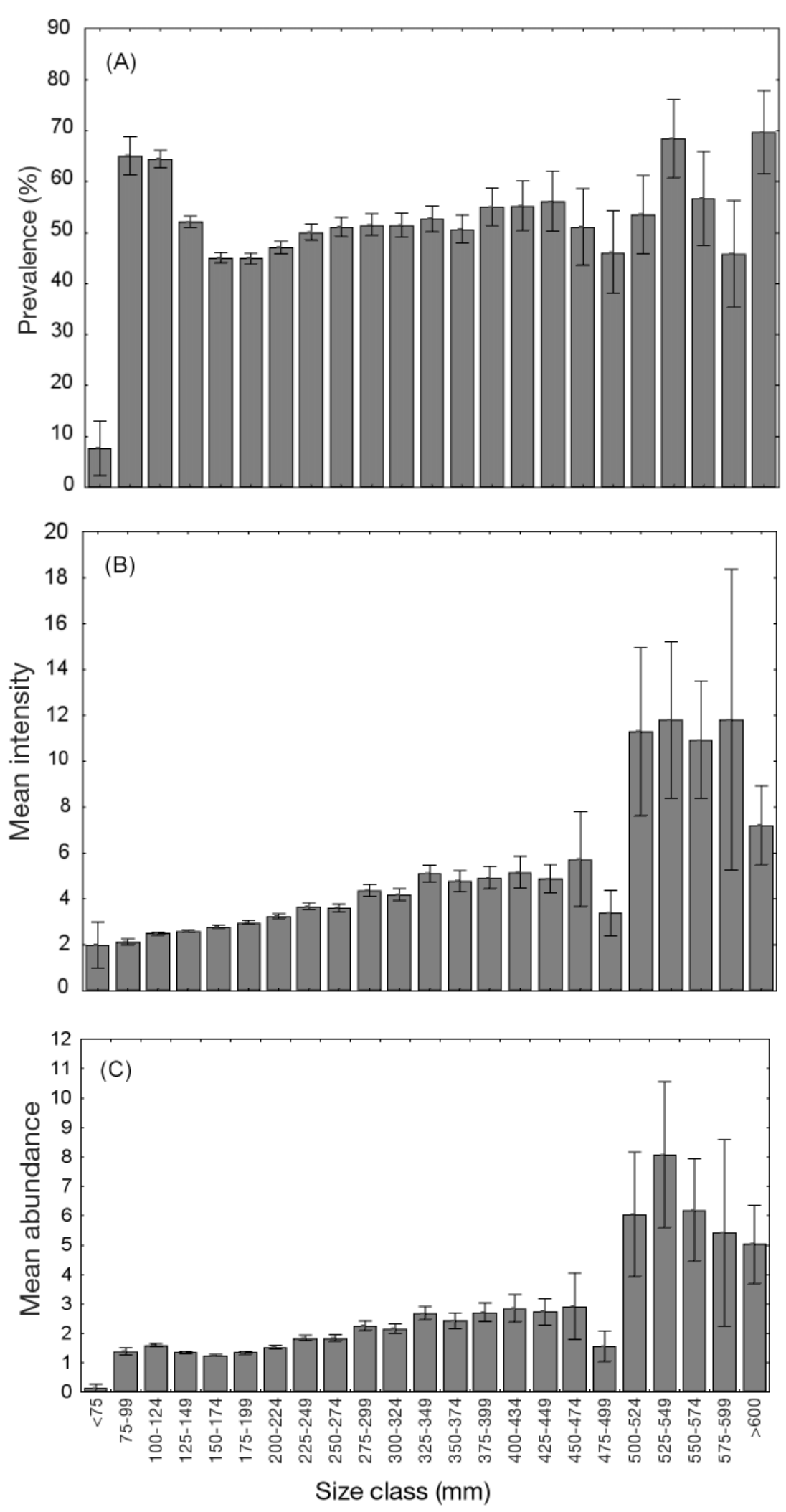

Fig. 4. Anguilla anguilla. (A) Mean $( \pm \mathrm{SE})$ prevalence, $(\mathrm{B})$ mean $( \pm \mathrm{SE})$ intensity (no. of parasites per infected host) and $(C)$ mean $( \pm \mathrm{SE})$ abundance (no. of parasites in all eels sampled) as a function of eel size. Size-classes are in millimetres, with $25 \mathrm{~mm}$ intervals sites than younger fish); (2) larger host area (body size) for parasite establishment; (3) higher consumption of infected prey with increasing host size. The positive relationship we report here is of particular interest, because it was observed for an association in which the life cycle of the parasite is relatively short compared to the life span of the host. To some extent, this means that eels suffer continuous parasite pressure either via re-infection(s) or via the maturation of parasite larvae in arrested development in the tissue layers of the swimbladder wall (Ashworth \& Kennedy 1999).

However, the probability of harbouring lumen worms is not constant throughout all eel size-classes. The prevalence was first low $(8 \%$ in eels smaller than $75 \mathrm{~mm}$ in length), then relatively high $(65 \%$ between 75 and 124 $\mathrm{mm}$ in length) before suddenly decreasing in the subsequent size classes (45\% between 175 and $199 \mathrm{~mm}$ in length). In the literature, some authors have reported a decrease in the prevalence of lumen worms with increasing host length (Möller et al. 1991), while others have noted an increase (Thomas \& Ollevier 1992, Baruš et al. 1996). The disparity is probably related to the variations we observed among elver eels.

The observed trends in prevalence and intensity produced a bell-shaped curve of parasite abundance as a function of host size (50 to $175 \mathrm{~mm}$ ). Theoretical studies and empirical investigations have postulated that a local decrease in mean parasite abundance may reflect host mortality i.e. the deaths of heavily infected hosts (Gordon \& Rau 1982). However, alternative hypotheses could also account for the observed decrease in parasite abundance. For example, eels are known to change their alimentary diet during the elver phase, first feeding on planktonic crustaceans, and then becoming increasingly piscivorous (Tesch 1977). Thus, the differential infection rate could also result from a differential efficiency of the parasite transmission between intermediate and paratenic hosts. 
Acknowledgements. We would like to thank Gilles Poizat, Serge Morand and Vincent Boy for their constructive comments on the manuscript. We are also grateful to Anna Saltmarsch for English corrections. This study was supported by the Foundation Tour du Valat.

\section{LITERATURE CITED}

Ashworth ST (1994) Possible regulation in the Anguillicola crassus host-parasite system. In: Pike AW, Lewis JW (eds) Parasitic diseases of fish. UK Samara Publishing, Tresaith, Dyfed, p 141-150

Ashworth ST, Kennedy CR (1999) Density-dependent effects on Anguillicola crassus (Nematoda) within its European eel definitive host. Parasitology 118:289-296

Barse AM, Secor DH (1999) An exotic nematode parasite of the American eel. Fisheries Bethesda 24:6-10

Baruš V, Prokeš M (1996) Length-weight relations of uninfected and infected eels (Anguilla anguilla) by Anguillicola crassus (Nematoda). Folia Zool 45:183-189

Baruš V, Halačka K, Prokeš M (1996) Presence and distribution of the nematode Anguillicola crassus in the European eel in the Morava river drainage basin, Czech Republic. Zivoc Vyroba 41:219-224

Békési L, Hornok S, Székely C (1997) Attempts to analyse Anguillicola crassus infection and the humoral host response in eels (Anguilla anguilla) of lake Balaton, Hungary. Acta Vet Hung 45:439-445

Benajiba MH, Silan P, Marques A, Bouix G (1994) Protozoaires et métazoaires parasites de l'anguille Anguilla anguilla L., 1758: structures temporelles de leurs populations dans une lagune méditérranéenne. Ann Sci Nat Zool Biol Anim 15:141-149

Blanc G (1994) Biologie du cycle d'Anguillicola crassus (Nematoda, Dracunculoidea) - contrôle thérapeutique de ses populations. Thèse doctorat, Université Perpignan

Buchmann K, Pedersen LO, Glamann J (1991) Humoral immune response of European eel Anguilla anguilla to a major antigen in Anguillicola crassus (Nematoda). Dis Aquat Org 12:55-57

Burnham KP, Anderson DR (1998) Model selection and inference: a practical information theoric approach. Springer, New York

Bush AO, Lafferty KD, Lotz JM, Shostak AW (1997) Parasitology meets ecology on its own terms: Margolis et al. revisited. J Parasitol 83:575-583

Cesco H, Lambert A, Crivelli AJ (2001) Pseudorasbora parva (téléostéen, Cyprinidae) espèce invasive, nouvel agent du maintien et de la dissémination de l'anguillicolose en France? Parasite 8:75-76

de Charleroy D, Grisez L, Thomas K, Belpaire C, Ollevier F (1990) The life cycle of Anguillicola crassus. Dis Aquat Org 8:77-84

Dogiel VA, Petrushevski GK, Polyanski YI (1958) Parasitology of fishes. Oliver \& Boyd, London

Dupont F, Petter AJ (1988) Anguillicola, une épizootie plurispécifique en Europe: apparition de Anguillicola crassa (Nematoda, Anguillicolidae) chez l'anguille européenne Anguilla anguilla en Camargue, Sud de la France. Bull Fr Pêche Piscic 308:38-41

Fries LT, Williams DJ, Johnson SK (1996) Occurrence of Anguillicola crassus, an exotic parasitic swim bladder nematode of eels, in the southeastern United States. Trans Am Fish Soc 125:794-797

Gordon DM, Rau ME (1982) Possible evidence for mortality induced by the parasite Apatemon gracilis in a population of brook sticklebacks (Culaea inconstans). Parasitology 84: 41-47

Hartmann F (1994) Untersuchungen zur Biologie, Epidemiologie und Schadwirkung von Anguillicola crassus Kuwahara, Niimi \& Itagaki 1974 (Nematoda), einem blutsaugenden Parasiten in der Schwimmblase des Europäischen Aals (Anguilla anguilla), 1st edn. Shaker Verlag, Aachen

Höglund J, Pilström L (1995) Mechanical isolation and characterization of antigens from adult Anguillicola crassus. Fish Shellfish Immunol 5:51-60

Kelly CE, Kennedy CR, Brown JA (2000) Physiological status of wild European eels (Anguilla anguilla) infected with the parasitic nematode, Anguillicola crassus. Parasitology 120:195-202

Kennedy CR, Fitch DJ (1990) Colonization, larval survival and epidemiology of the nematode Anguillicola crassus, parasit in the eel, Anguilla anguilla, in Britain. J Fish Biol 36: $117-131$

Kirk RS, Kennedy CR, Lewis JW (2000) Effect of salinity on hatching, survival and infectivity of Anguillicola crassus (Nematoda: Dracunculoidea) larvae. Dis Aquat Org 40: 211-218

Knopf K, Naser K, van der Heijden $\mathrm{MH}$, Taraschewski $\mathrm{H}$ (2000) Humoral immune response of European eel Anguilla anguilla experimentally infected with Anguillicola crassus. Dis Aquat Org 42:61-69

Køie M (1991) Swimbladder nematodes (Anguillicola spp.) and gill monogeneans (Pseudodactylogyrus spp.) parasitic on the European eel (Anguilla anguilla). J Cons Int Explor Mer 47:391-398

Kuwahara A, Niimi A, Itagaki H (1974) Studies of a nematode parasite in the air bladder of the eel. I. Description of Anguillicola crassa n. sp. (Philometridae, Anguillicolidae). Jpn J Parasitol 23:275-279

Möller H, Holst S, Lüchtenberg H, Petersen F (1991) Infection of eel Anguilla anguilla from the River Elbe estuary with two nematodes, Anguillicola crassus and Pseudodactylogyrus decipiens. Dis Aquat Org 11:193-199

Molnár K, Székely C, Perényi M (1994) Dynamics of Anguillicola crassus (Nematoda: Dracunculoidea) infection in eels of Lake Balaton, Hungary. Folia Parasitol (České Budějovice) 41:193-202

Moravec F (1994) Parasitic nematodes of freshwater fishes of Europe. Academia, Praha

Moravec F, Skoríková B (1998) Amphibians and larvae of aquatic insects as new paratenic hosts of Anguillicola crassus (Nematoda: Dracunculoidea), a swimbladder parasite of eels. Dis Aquat Org 34:217-222

Nagasawa K, Kim YG, Hirose H (1994) Anguillicola crassus and Anguillicola globiceps (Nematoda: Dracunculoidea) parasitic in the swimbladder of eels (Anguilla japonica and A. anguilla) in East Asia. Folia Parasitol (České Budějovice) 41:127-137

Neumann W (1985) Schwimmblasenparasit Anguillicola bei Aalen. Fischer Teichwirt 36:322

Nielsen ME (1997) Infection status of the swimbladder worm, Anguillicola crassus in silver stage European eel, Anguilla anguilla, from three different habitats in Danish waters. J Appl Ichthyol 13:195-196

Nimeth K, Zwerger P, Würtz J, Salvenmoser W, Pelster B (2000) Infection of the glass-eel swimbladder with the nematode Anguillicola crassus. Parasitology 121:75-83

Peters G, Hartmann F (1986) Anguillicola, a parasitic nematode of the swimbladder spreading among eel populations in Europe. Dis Aquat Org 1:229-230

Poulin R (2000) Variation in the intraspecific relationship 
between fish length and intensity of parasitic infection: biological and statistical causes. J Fish Biol 56:123-137

Tesch FW (1977) The eel: biology and management of anguillid eels. Chapman \& Hall, London

Thomas K, Ollevier F (1992) Paratenic hosts of the swimbladder nematode Anguillicola crassus. Dis Aquat Org 13: 165-174

Thomas K, Ollevier F (1993) Hatching, survival, activity and penetration efficiency of second-stage larvae of Anguillicola crassus (Nematoda). Parasitology 107:211-217

van Banning P, Haenen OLM (1990) Effects of the swimblad-

Editorial responsibility: Wolfgang Körting,

Hannover, Germany der nematode Anguillicola crassus in wild and farmed eel, Anguilla anguilla. In: Perkins FO, Cheng TC (eds) Pathology in marine science. Academic Press, New York, p 317-330

van Willingen J, Dekker W (1989) 1988 update on Anguillicola in Dutch outdoors waters. EIFAC (FAO) Working Party on Eel, Porto

Würtz J, Knopf K, Taraschewski H (1998) Distribution and prevalence of Anguillicola crassus (Nematoda) in eels Anguilla anguilla of the rivers Rhine and Naab, Germany. Dis Aquat Org 32:137-143

Submitted: July 10, 2001; Accepted: March 6, 2002

Proofs received from author(s): July 9, 2002 